\title{
Article \\ Metaphysics and Mysticism: Mystical Aspects and Elements in the Work of Czech Thinker Karel Ríha
}

\author{
Martin Vašek ${ }^{1, *(\mathbb{D}}$, Andrea Blaščíková ${ }^{2, *(\mathbb{D}}$ and Rastislav Nemec ${ }^{3}$ (D) \\ 1 Department of Philosophy, Faculty of Arts, Constantine the Philosopher University in Nitra, Hodžova 1, \\ 94974 Nitra, Slovakia \\ 2 Department of Religious Studies, Faculty of Arts, Constantine the Philosopher University in Nitra, \\ Hodžova 1, 94974 Nitra, Slovakia \\ 3 Department of Christian Philosophy, Faculty of Theology, Trnava University, Kostolná 1, P.O. Box 173, \\ 81499 Bratislava, Slovakia; rastislav.nemec@truni.sk \\ * Correspondence: mvasek@ukf.sk (M.V.); ablascikova@ukf.sk (A.B.)
}

check for updates

Citation: Vašek, Martin, Andrea Blaščíková, and Rastislav Nemec. 2022. Metaphysics and Mysticism: Mystical Aspects and Elements in the Work of Czech Thinker Karel Říha. Religions 13: 84. https://doi.org/ $10.3390 /$ rel13010084

Academic Editor: Rob Faesen

Received: 12 November 2021

Accepted: 12 January 2022

Published: 17 January 2022

Publisher's Note: MDPI stays neutral with regard to jurisdictional claims in published maps and institutional affiliations.

Copyright: (C) 2022 by the authors. Licensee MDPI, Basel, Switzerland. This article is an open access article distributed under the terms and conditions of the Creative Commons Attribution (CC BY) license (https:// creativecommons.org/licenses/by/ $4.0 /)$.

\begin{abstract}
Czech theologian and philosopher Karel Říha (1923-2016) followed the thinking of Maurice Blondel. He wanted to expand and deepen the basis of transcendental philosophy. He perceived the possibilities of a new metaphysics, which would be established only in a triadic way of thinkingknowledge, wanting, Being. He originally believed that the basic philosophical theory was the theory of moral conversion. Říha comprehended the event of moral conversion as a mystic turn, a transformation in which we find ourselves by realising ourselves in devotion to others. In this transformation, the striving for metaphysics, which is based on interpersonal relationships, achieves its goal. Metaphysics eliminates itself and is integrated into theology. Theology finally comes to the conclusion that the truth is not in our power but pursues us. The theologian and philosopher Ř́ha, as he writes, has united himself with a Will, which we do not know where it leads us or what it will ask from us. There was nothing left on his own. Metaphysics and mysticism are united in his thinking and work.
\end{abstract}

Keywords: Karel Říha; Maurice Blondel; conversion; metaphysics; mysticism; Christian philosophy

\section{Introduction}

In the work of the Czech Christian philosopher, theologian, translator, and Jesuit priest Karel Říha ${ }^{1}$ (1923-2016), we can undoubtedly see the mystical aspects and elements that we would like to illustrate in our study. The mystical experience is integrated into his work which is based on this experience. In the homily at the funeral mass for Father Ríha, we could hear that he had managed to grasp and live his first mystical experience of youth, as well as other mystical experiences, such as an encounter with the living God. For him, it was the God of the Christian faith, the traditions of his parents, neighbours and the Church in general. An important inspiration for him was Blondel's "philosophy of action", which, according to Říha, is based on the basic intuition that free decision opens the space for new experience, or-in other words-according to which action and contemplation are mutually conditioned. This corresponds to the understanding of the truth-in contrast to the abstract "harmony of reason and thing", Blondel put a "concrete harmony of mind and life" - adaequatio realis mentis et vitae. ${ }^{2}$ Let's add, as M. A. Conway points out, "Blondel argues against reducing the mystical life to a metaphysics (...) and so, clarifies repeatedly the importance of attending to practice in conjunction with theory. Whatever knowledge St. John (of the Cross-author's note) has is always at the service of the practical design and is never for its own sake; it has ultimately as its object the lived nescience that leads to what Blondel terms a 'true Ontology'" (Conway 2018, p. 671).

Ŕiha spoke about the need and at the same time about the overcoming of metaphysics, its completion-metaphysics is integrated into theology and at the same time about the 
exigency of metaphysics for theology. The contemporary Czech theologian František Štěch believes that Karel Říha's unequivocal contribution to Czech theology and especially to fundamental theology is the fact that he tried to make Blondel's work systematically accessible to domestic researchers. It thus enabled them to integrate themselves into the theological tradition inspired by this important French philosopher (Štěch 2014b, p. 76). In addition, in Říha's work, the requirement of dynamic theology is particularly interesting, which in a unique way not only reflects the mentioned philosophical motives, but also considers the changed circumstances of the addressee. The combination of philosophical and theological motives - as we will try to show in this article-blends seamlessly with the level of mystical experience in his work.

According to the Czech philosopher, Blondel's "philosophy of action" does not presuppose anything, because every presupposition can only be mastered by action. There is a basic willing (wanting) ("la volonté voulante", willing will) at work in human activity, which is consistent with universal action, but which can only be concretised by willed limited objects ("la volonté voulue", willed will). ${ }^{3}$ Since no object suffices for the infinite range of willing, we are faced with the alternative of either giving ourselves over to that which is not at our disposal or closing ourselves off to it. Thus, from Říha's point of view, Blondelism is a philosophy of human insufficiency that leads one to the threshold of a decision between religious faith and the denial of faith. The denial of faith is the violent suppression of the infinite power of the human spirit and the choice of what is finite. To use Blondel's words: "Whence this conclusion, which is not only that of the mystics, but that of the common law of Christian life: one acquires the infinite only by accepting beforehand the voluntary renunciation of all that is finite insofar as it is finite" (Blondel 2021b, p. 138).

The study is divided into three main parts. The first part is a probe into the autobiographical prose of Karel Říha. In them, Říha describes a mystical experience he went through in his youth. For him, this experience was the beginning of a new life. The life that is not consumed by providing itself but fulfilled by surrendering oneself. His philosophy is a part of this life. It has its origin in the desire to clarify the questions related to the search for identity. Who am I? Is my identity based on the laws of nature or is it something I shape through free decisions? Does action come from understanding or is understanding born out of action? What is the relation between identity and transformation? Reflections on these questions stem his theory of moral conversion, which he believed to be a basic philosophical theory. The first part of the study presents this theory and its mystical aspects. It compares it with the theory of conversion of Czech philosopher Radim Palouš. The conclusion of the first part reveals the leitmotif of Říha's philosophical testament: the interpenetration of Being, thinking and willing in the principles of identity and relevance.

In the second part we will present Říha's original and specific-Blondel-inspired"metaphysics of identity and relevance". This metaphysics is founded on a triadic thinking that distinguishes and simultaneously unites Being, thinking, and knowing in their mutual cyclical determinations, thus defining itself against the linear thinking of intellectualist metaphysics. The principle of identity and relevance are just another version of the triadic concept. Thinking according to the principle of identity does not sufficiently clarify the subject as subject, nor is it sufficient to grasp the beings imposed on our action; hence we also need the principle of relevance. Just as the principle of the identity of Being is the basis of thought and metaphysics, so the principle of relevance is the basis of interpersonal relations and ethics. Metaphysics is not only possible but also necessary because it is a natural human capacity; however, it must take interpersonal relationship into account. To establish metaphysics in this way means to exceed its classical requirements.

The third part of this study seeks to show the relationship between ontology (metaphysics) and mysticism. In this sense, it is interesting for our purpose in what way Ríha-in contrast to modern philosophy, which prefers the criterion of knowledge-chooses rather the principle of will, in which he was inspired by M. Blondel. At this point, he establishes the preconditions for mystical experience and the new, interesting interpretation of nihilism that modern philosophy brought with it. At the same time, it appears that metaphysics 
seems to contain a mystical aspect, which is then explicitly and fully developed (completed) by theology/mysticism.

\section{Mystical Experience and Conversion Theory}

Karel Říha was convinced that there are situations in one's life when the question of his meaning is intensely experienced. These are often events of crisis, and threats in which certainties fall apart and the overall meaning of life can be saved only by a person's determination to go through a deeper level of reflection (Říha 1990, p. 327). In this reflection, man's desire to find his true identity comes forth while trying to answer the question: "Who am I?" Říha believes that the secret of the answer to this most personal question can be revealed to man only by God (Říha 1993, p. 80). It is therefore associated with the abandonment of self-centeredness, with an inner rebirth, similar to that pointed out by many religious and philosophical sources.

Karel Ríha experienced crisis and inner rebirth for the first time during his studies at grammar school. In his personal narrative, he recounted the seemingly insignificant situation to which it referred. After returning to school from vacation, he was called upon to conjugate Latin verbs. Unable to remember the grammar rules, he tried to hide his embarrassment with a smile. The Latin teacher not only scolded him for his unpreparedness, but also misinterpreted the smirk on his face. She affected him more deeply than she could have expected. Karel Říha suffered from a facial paresis as result of which he could not control his facial expressions so his smile could have resembled a wry face. The teacher caused his inner drama and re-opened the wound of mockery he had experienced as a child from his peers. At that very moment, in the midst of the feelings which disturbed him for the next few days, when he unexpectedly and inexplicably experienced something, he later expressed in these words: "A strange tenderness seeped into my heart: compassion for all beings forgotten, trampled, suffered. In them I accepted and embraced my destiny. But without any trace of self-pity. Suddenly I felt firm, calm, and strong. Here, I think every attempt to explain it psychologically is insufficient. I stopped revolting. I reconciled with myself and all creation. I left my ivory tower and went into space opened to all directions, defenceless and invulnerable" (Říha 2010, p. 16).

Later, he called this reconciliation the beginning of a profound contemplative life, the beginning of a new world. He was no longer the center of this world, closing in his pain, clinging to earthly hope. He opened himself to the language of nature, entrusted to its motherhood and through it to its deeper meaning, the motherly womb of God (Ř́íha 2010, p. 59). He surrendered to love and found in it his mission and identity deeper than our face can express. Not only in himself, but also in other people, he began to see their true, good core, the grandeur of their vocation, although they often hid themselves under a superficial and deceptive life. He tried to understand them, look at their needs and help them to be happy and good. He understood the fear that kept a person at the "familiar shore" and prevented him from entering an unsecured space, entrusting himself to the mysterious call that is heard in the desire of the heart and to which we are called unconditionally as a duty of conscience. At the same time, he knew that a new life that we had no idea about before would be revealed to us only if we die to self and take a step into the unknown space. And it took a long time, in his own words, till the peace of this vision began to be a part of his everyday life. Undoubtedly, his journey started with this experience of rebirth.

Karel Říha constantly deepened the reflection on his personal conversion experience. He revealed in it the connection between mysticism and the living relationship of faith on one hand and theology and philosophy on the other. And although he realised that no theory could fully explain or induce a mystical experience of transformation, a philosopher and theologian may still ask himself the question: What is and what is not conversion? $\mathrm{He}$ expressed his observations on this topic in a review study of the book Čas výchovy (The Time of Education) by Czech philosopher and pedagogue Radim Palouš.

Radim Palous ${ }^{4}$ based the formulation of his thesis on the life conversion, which is a mission of education, from three historical concepts: the conversion of the consecrated 
according to the Eleusinian mysteries, the Platonic periagogé and the conversion in the Christian spirit. According to him, these three traditions, despite their differences, coincide in the essential statement: one does not know oneself until the experience of turnover, conversion. What a man learns from him and his manifestations before this experience are only fragments of the manifestations of his " $\mathrm{I}$ ", not the real answer to the issue of identity. The identity of man is not and cannot be corporeality. The body changes its cells several times during one's life; it is subject to change, so it could hardly be a guarantor of a perpetual identity. Is the identity in the memory, in the fact that we remember parts of our life story and that these remain in us even though the body changes? Palouš also refutes this hypothesis, because after the conversion we remember what was before as if "from the other side" (Palouš 1991, p. 135). A person who has experienced his conversion also sees his past in a new light, he interprets it from the point of view that has been revealed to him. Then, he is convinced what his true identity is. It remains to be asked whether a person's unique identity lies in autonomous decision-making. But Radim Palouš also disagrees with this way of thinking. That what I am, I do not create by my ordinary decisions, by choosing what is more beneficial to me. According to him, in the background of such an idea, there is a man, as a peculiar, independent, and self-projecting being who decides for himself. A man who chooses the best for himself from his sovereignty. But is a man really such a ruler over himself and over the world? Has modern psychology not disproved this idea? Hasn't it revealed that a man is determined both sociologically and psychologically? However, if Palouš rejects the image of the identity of man-a sovereign and ruler over his life, he similarly considers the image of man inappropriate-as a slave of various influences (Palouš 1991, pp. 109-11). Is it even possible to find an answer to the question of who I am? Doesn't this answer remain hidden? According to Palouš, the Eleusinian mysteries, the Platonic periagogé and the Christian descriptions of conversions concur that one cannot find the answer until he wants to find it from his own sources. On the contrary, he often opens up to answers in helplessness, in the loss of confidence in acting independently. The failure of one's own proofs and plans is precisely the inner emptiness that opens the possibility of accepting a gift, capturing the challenge to enter into a relationship in which the " $\mathrm{I}$ " is called to the divine challenger. The task assigned to man, then, is not to know himself by self-awareness or by reflection, but rather to overcome everything that is not honest in this relationship of a call and response. A person who was called does not have ready-made answers, nor his destiny, but he is the one who strives for fidelity, who avoids every logic of calculation, which could disrupt that relationship. Through this honesty, the changeable "I" opens itself to accept the fullness of meaning as the truth about oneself. According to Radim Palouš, the real and unshakable identity of a person lies in an irreplaceable and unchangeable relationship between the challenge coming from above and the human response. It lies in the responsibility of man to the pre-ordinated claim (Palouš 1991, p. 135). Consequently, the events of human life are not just a series of meaningless moments, considered according to human will and benefit. Their significance is given by the task of answering the claim of the challenge, of proving their loyalty to the challenge. From the "other side" perspective, therefore, human identity turns out to be a task that takes place. Its immutability is in the duration of the challenge, in its inevitability, in its constant presence, in anticipation of our response, of our responsibility.

Říha positively appreciated the magnificence of Paloušs philosophy of education. Paloušs appeal to an act of trust, to confide, which is not calculated by the logic of benefits, was not only in accordance with his own experience of conversion, but also with Blondel's philosophy of action. Not by one-sided thinking and considering the possibilities, but by action, by leaving the well-known shores, trust opens a new horizon of thought to a man, in which new meaning appears, and a new world arises (㠩ha 1990, p. 328). It is therefore not enough to develop the possibilities of our thinking, it is not enough to educate our reason about who a man is in abstract notions, but a man is called to act in order to know who he is. "In order to think at all, we must act, and in order to act, we must relate to reality" (Říha 1993, p. 79). Thinking, acting and Being are three dimensions that are interdependent. 
Although Palouš's philosophy of conversion has an immense and unquestionable importance from the point of view of the theory of education, from the speculative point of view Ř́ha considered it necessary to think more about Palouš's understanding of identity. He believed that establishing identity in responsibility, in response to a challenge, moved us very close to voluntarism, which, such as unilateral intellectualism, is an extreme movement. According to Říha, Palouš emphasises the "pre-ordinated claim" at the expense of the "truth co-ordinated to man". It would mean that what is to be precedes the being itself. Řiha does not agree with that. According to him, submitting to one's unique profession is only one side of conversion. The second is an acceptance of oneself, reconciliation with oneself, even with an erroneous, insufficient claim (Říha 1990, p. 334). The conversion, then, is already in accepting oneself, in accepting what really is, not just in devotion to the call to realise what is to be. Intellect, will and Being must correlate.

In Říha's own way of thinking, the question "Who am I?" embraces thinking, wanting, and Being as a principle of identity and a principle of relevance. As far as the notion of "identity" is concerned, Řiha expresses the harmony of the mind with what really is. In the principle of identity, thinking and Being encounter. However, in the mind of personal being, there is an awareness of the tension between what is now and the claim to be. This claim precedes and motivates our self-realisation. To understand the challenge is to realise the obligation to devote to a higher will, which entrusts us with the task of completing ourselves by surrendering ourselves. Thus, through the principle of relevance, Ríha wants to express the fact of our compliance with the challenge, the implementation of which is entrusted to the will. It is the fulfillment of our identity and attaching importance to our personal identity (Říha 2014a, pp. 120-21).

Czech theologian Karel Skalický interprets the principle of relevance as a paradox because relevance lies in the fact that a person becomes what he is only if he wants to be non-self, or in other words, when he wants to be united with You. While the principle of identity is more about knowledge, in the principle of relevance it is more about will, love (Skalický 2014, p. 34). A person comes out of himself to meet another, to surrender to him in love, and to become what he is called to be according to the call of conscience. According to Skalický, Řiha's principle of identity is an intellectual-essential principle, while the principle of relevance is a volitional-existential principle (Skalický 2014, p. 36). Knowledge, Being and action illuminate each other. A man cannot be himself, even in reason, he cannot find the answer to the question of who he is, unless he comes out of himself, unless he falls himself into the ocean of love and entrusts his securing and calculating will to the divine will. When he does so, reason acquires a new perspective, from which he sees what was previously hidden from him, he also more truly perceives his identity.

Thus, there is and should be constant conditioning between identity and relevance. I find myself coming out of myself into an act by which I realise the call to devotion, a call to a relationship. As a result of the following action, I have a new knowledge of myself. Theologically, however, it is not only our effort, but this effort itself is already carried by God's grace-bestowed or offered; it is a grace that we can neither force nor evoke, but with which we can only cooperate (Říha 1993, p. 80). Říha refers to this grace as a "light power". It is the power that transcends human understanding and that amazes us. It is also a force that helps us to step into space, it helps us to decide to surrender. This power accompanies a man as a light giving direction and duty; it is the splendour of conscience. At the same time, this light is the power that directs a person, carrying him over his hesitation and fear. A man is not able to grasp this force and arrange it for the future, he can only devote to it in his confidence. Gradually, he finds out that he is carried by it and that it does not have to be afraid, even though its glow falls over the horizon and the tangible experience of love is taken away. The mystical experience that was at the beginning of a birth of new life in him, as he decided to act, will continue to accompany him as a deep-seated peace and faith that he will always receive a new assurance that he is accepted and loved (Ríha 1987a, pp. 118-19). 


\section{Metaphysics of Identity and Relevance}

Říha tried to unify noetic idealism and realism. He found that unities in the activity of the spirit-in this activity Being, knowledge and desire are cyclically determined. These three moments of spirit activity form the basis of unity and discernment, the basis of ontology (or metaphysics) and ethics. They form (generate) a broader basis than the metaphysical concept of Being, which is able to open up to new thinking or we can construct a new way of thinking on it.

According to the Czech author, neither metaphysics nor ethics itself are the first philosophy (prote philosophia) and metaphysics cannot be based on ethics, as Lévinas thought. Therefore, he tried to find another approach that was found in Maurice Blondel, in transcendental philosophy, in phenomenology and in dialogical personalism. Říha wanted to broaden and deepen the starting point of transcendental philosophy, because he saw in it the possibilities of a new metaphysics, which would be possible only in a triadic way of thinking-Being, knowledge, desire. He refers to Blondel, who took the concept of circumincession (J. S. Eriugena's perichoresis) from theology to express the inseparability and at the same time the distinguishability of three truths-ontological, logical, and moral—or in other words—Being, Truth and Love.

"The word circumincession evokes in fact the idea of a reciprocal causality, no longer in time and space, but in a contemporaneity and in a unity which are tightened by the very distinction of the sublime functions in which we still have to try to penetrate a little further" (Blondel 1935, p. 174).

Circumincession in human activity is a kind of imitation of the relationships of persons in Trinity. In our proceedings, this reciprocity-as in the mystery of the Trinity-is updated in a dialogue. This allows the cycle of mutual relations to take place in both directions. ${ }^{5}$

According to Ríha, Blondel emphatically proclaimed the impossibility of separating and isolating the three individual moments of activity. He quotes his words: "Abstracted from all else, the naked intelligible is, in a sense, perfectly unintelligible, just as pure Being is non-sense, non-existence, and as 'pure Love' is false charity, a chimera destitute of solid foundations and moral character without which there can be neither goodness nor true subsistence" (Blondel 1966, p. 155; Ciraulo 2021, p. 330). Elsewhere Blondel writes: "What is disconcerting to us in ourselves, is that we cannot equal ourselves; what is disconcerting to us in it, is the absolute equation of being, knowing, and acting" (Blondel 2021a, p. 380).

Ř́na was convinced that the horizon of knowledge and the horizon of desire are two different horizons. They are infinite and unattainable. However, it is possible to demonstrate that the activity of theoretical reason (knowledge) in its last foundation depends on the free self-determination of practical reason (desire) and vice versa. This means that ontology and ethics are determined and constituted simultaneously. However, if there is the third basic moment of activity, i.e., Being, then these activities are unified in

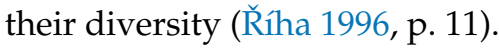

Metaphysics based on these starting points would precede two reproaches. The first reproach is that metaphysics in general leads to the rule of the subject over the world of objects. According to the second reproach metaphysics does not allow us to reflect on history and interpersonality. Říha's metaphysics thus overcomes these problems or solves them. In the triadic thinking, inspired by Blondel, the Czech author saw a broader base of metaphysics, in which we can think of a radical plurality of beings and not lose their connection. However, we do not understand beings in the category of essence, but relations, and thus prevent the objections of postmodernism to classical metaphysics (Říha 2007, p. 8; 2014b, pp. 128-29).

According to Říha, the mystics found only emptiness in themselves and warned against self-immersion, against empty self-reflection. The immersion itself gradually leads to a loss of sense of reality, to emptiness and nihilism. This tendency must be overcome by a movement that moves away from oneself to the other. Relation to the other is a priori friendliness without returning to oneself, as Lévinas thought. For this a priori spiritual impulse the Czech author chose the term relevance. Let us recall and add that mystics 
perceived God's presence in their consciousness as an encounter with a loved one, to whom God's spirit encourages them. God's spirit wants to lead a man to his original image and to a loving unity. The mystical consciousness is thus constituted as a relationship-it opens to the Other (Kučerková 2020, p. 20).

The correlative notion of relevance is identity. Identity means Self-being (Selbstsein). An abstract understanding of identity leads to a formal understanding of metaphysics: metaphysics is based only on the formal principle of identity (Štech 2014a, p. 81). Another consequence of the abstract understanding of identity is that ethics is also reduced, insufficiently defined and understood because it is based on the non-relational nature of man. On the other hand, if we exclude relevance from the relationship to identity, if we understand relevance without identity, we will reach the absolutisation of the Other as in Lévinas's ethics. Concurrently, we eliminate self-awareness from the field of ethics, the significance of self-reflection of subjectivity. However, the meaning of one's own identity cannot be given other than by a free turn to the other man. Finding a relationship of agreement with another according to the principle of relevance is possible only if one maintains his own identity. "I am myself" - the principle of identity, absolute self-affirmation is a purely formal relationship to oneself, meaningless and therefore useless. "I should be different" — the principle of relevance is an impossible task. Only self-affirmation for the sake of the other and the acceptance of the other under the condition of preserving one's own identity are real and authentic activities. For this reason, the query of God is also posed in a new way. It is a query of the last cause of human activity, which manifests itself in lived metaphysics and in rationally derived ethics. The dialectic of thinking and acting refers to the absolute Necessity, which is at the same time the absolute Freedom-to God (Říha 2005, pp. 38-39).

Pure identity is unconscious because it is unrelated to other. Pure relevance is the accession in empty space and thus as an anticipation of death. The unity of pure identity and pure relevance, of necessity and freedom, is a quality of God. A man can participate in it only if in certain sense he goes through spiritual death, the "zero point" (Ŕiha 2014a, p. 122).

According to Ř́ha, while the principle of identity expresses something "given," it does not immediately imply something "obvious" and clear. Rather, it is something whose essence appears to us as static. At this point, according to Řiha, all ontologies are identical when they name "fixed" components of reality. However, according to the Czech author it is not at all clear what it means when we say that "something exists", because the very fact that "something exists" hides within itself the depth of existence-and in the case of existence, it is not just a matter of sheer facticity. It is this that he accuses modern philosophy of looking at things only through the aspect of subjective knowledge.

The lack of this classical ontological concept becomes apparent when we realise that man, by his spirituality, transcends that "facticity". Through his activities, such as desire, by his activities such as longing, seeking, questioning, which are the essence of the expression of his spirituality, man does not identify himself with the fixed categories of other things. The spirit of man symbolizes above all activity. In this way he transcends the reality around us, the ordinary facticity and immanence. In contrast to classical ontology, Ríha here offered the contours of what M. Blondel had already called the principle of dynamism, of activity, of difference (not-self), irreducible to pure givenness. He characterised man above all through the aspect of what he is not and what is expressed by his spiritual activity - that is, what he is striving for, heading towards. Man is thus characterised more by what he is not yet and what he does not yet have, but what he desires.

In this sense, the Rahnerian reditio completa, by which he wanted to capture man's spirituality, also seems to Řiha to be insufficient. While it is true that man can look away from what he is and consider what he is not. He knows how to return to his inner self and reflect on his thinking. This is how Rahner characterises him through the aspect of openness, searching, questioning, expectation, hope. It is this incompleteness and searching that Rahner captures in the example of the question in which both Rahner and Coreth agree. 
The question is, according to Rahner and Coreth, the first phenomenon of the conscious life of a man; it is the beginning of thinking and the anticipation (Vorgriff) of the answer. In this anticipation a person "has" something (what he knows), therefore he can ask. He has a deposit, an advance, but at the same time he reaches for something unknown and has nothing (К̌íha 1972, p. 883). In this "span" the question gives him an ample reason to believe that he will find an answer to it, even though other questions emerge from it. But it seems to Ríha that Rahner captures this aspect of the search very formally through the aspect of the horizon of the question when he focuses on the transcendental conditions of our knowledge. Not to the other You. A horizon that is distant from us and that we will never reach cannot be quite the counterpart that addresses us a personal message-an

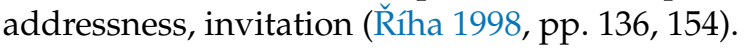

And so at least what the question achieves and what it learns is the direction and goal by which he realises where the question leads him and what cannot be answered. But also, by becoming a question to oneself, he enters the realm of "emptiness". He finds the search hopeless and the questions empty.

Therefore, Říha admits that in this sense the subject of the ontology is "nothingness". Nothingness in the sense of the unsuccessful search for man, his wreckage, which leads us to an important finding about our own inadequacy and incompleteness. It is this awareness that coincides with a "loss of meaning" as the first characteristic of the beginning of conversion. "Modern nihilism seems close to conversion" (Říha 1990, p. 332), because the "loss of meaning" is the first moment of finding the new one. The goal of ontology should be to "understand oneself as being on the horizon of the other". Ontology is not a doctrine of (only one) individual being, but of being as such. And as one thing does not make sense in ontology, so the constitutionality of the meaning of the world is not given by what comes only from ourselves, but by what had been here before us. And emptiness, nothingness, requires an interpretation that cannot be satisfactorily achieved at the level of ontology.

Ontology is therefore possible as the ontology of subjectivity, and the ontology of subjectivity is already a whole ontology. In the activity of the subject the Being is not only non-participatory, impartially stated, articulated but carried out and freely developed. It happens in a dialogue of knowledge and love. Ontology as a science is a theoretical aspect of this dialogue. It is possible only as an open system (Říha 1987b, p. 456; 1996, p. 11).

According to Řina, the original model of knowledge, which relates to the motionless centre of self-confidence, and which expands in a circle, must be replaced by an ellipse model. This ellipse is determined by the spacing of two focuses-self-awareness and selfdetermination, which are mutually conditioned. With their tension, they enable historical transformations of subjectivity itself. These relationships between knowledge, desire and Being need to be understood in an interpersonal context. Because only another person who claims us and whom we are responsible for radically breaks the immanence of our activity

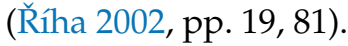

Metaphysics is a way of knowing, which is an expression of the fundamental openness of the human being. It turns to history and finds an emphasis in its structural and transcendental concepts. Just as human nature takes place only in interpersonal relationships, in dialogue and in its historical context, so metaphysics becomes alive and in life by leaning towards history. The last meaning of metaphysics is openness to God's revelation. The integration of history in metaphysics and metaphysics in history breaks the horizon of classical intellectualist metaphysics and opens new possibilities. As for the universal validity of logic, it is not questioned, but integrated into dialogical thinking, just as substantive ontology is integrated into the ontology of transcendental relations. The classical metaphysics is thus not denied but preserved and overcome. And we can speak together with Heidegger about the "Verwindung de Metaphysik" (Říha 2002, pp. 63, 96).

From Ríha's point of view, postmodern thinking is (or rather was) an intellectualistic system too. He distinguishes between theoretical and practical reason and realises that one cannot be without the other. Nevertheless, postmodern thinking has not concluded that the 
horizon of theory and practice is conditioned and determined by each other, quite radically. Each of the horizons is individually self-destructive and only in their reciprocity lies the whole consistency of human activity, values, and our world (Říha 2002, p. 93).

According to Říha, if we claim that intellectualist metaphysics is over, it does not mean that its possibilities are exhausted. It is therefore important to examine the project of metaphysics which is based not only on theoretical reasoning or a theoretical query, but on human activity as such. This activity is based on the unity of self-awareness and self-determination in relation to others and to Transcendence (Říha 2002, p. 155).

The principle of identity and relevance is just another expression of the triadic model of thought. Supplementing the principle of identity with the correlative principle of relevance implies a change of the original subject-object paradigm; the starting point in activity as such transcends the subject-object opposition. The subject-object paradigm, with its postulate of unchanging subjectivity, is incapable of perceiving interpersonal relationships, the creativity of the human spirit and the emergence of something new (because it requires overcoming stagnant ways of thinking). However, in the correlation of thinking, willing and Being, this is possible. For these reasons, Being is no longer understood as an object of knowledge, but only as a moment in the cyclical determination of human activity-along with knowing and willing. As far as the clarification of our existence insofar as Being is revealed in it is concerned, knowledge which is isolated from the other moments of activity is not sufficient for this. What is needed is the committed engagement of the whole person in action. Action is the "pivot" by which ontology and ethics are mutually grounded (Říha 2002, p. 145).

It is important to try the project of metaphysics, which is based not only on theoretical reasoning or theoretical questioning, but on human activity as such. This activity is based in the unity of self-consciousness and self-determination in relation to other persons and to Transcendence. It is essentially a metaphysics which, as a science, would try to understand (grasp) the complexity of relations, and which does not ground ethics, nor does it derive from ethics, but is co-founded, conditioned, and determined (together) with it (Říha 2002, pp. 154-55).

\section{Existential Level as the Starting Point for Theological and Mystical Experience}

Karel Říha was as rigorous in his criticism of the then existing metaphysical theories as his teacher Blondel. While Blondel, in his L'Action, criticises modern philosophy for forgetting to link concrete action to an abstract conceptual apparatus and for absolutising reason while forgetting the will's relation to the world (Bocken 2020, p. 51), according to Říha, modern philosophy cannot get rid of two presuppositions: on one hand, it cannot transcend consciousness and therefore remains isolated in subject and his consciousness. In this position, modern philosophy refuses to admit that there is anything beyond our consciousness. Hence the whole history of modernity is marked by the resolution of this paradox.

In the second place, analytic philosophy also resolves this paradox. The latter, by analogy, is aware of the limits of language and of its propositions (Říha 1998, p. 324) and cannot say with certainty whether there is any reality beyond the limits of language (Nichthintergehbarkeit der Sprache). Everything "beyond" language is somehow dark and obscure. Therefore, according to Říha, religious experience does not fit into these assumptions and automatically sounds like a step into the void in the sense of modernity. Theological statements are in turn, as meaningless. Human spirituality and spiritual values have been greatly questioned and marginalised. At the same time, however, Říha shows that this immanentism hides a paradox. By rejecting anything that exists outside of consciousness and language, the modern time has also, to some extent, called into question that which is being questioned - and to which both consciousness and language refer as their object. This is what might be called the way of reason.

Will and willing, however, lead one to admit something else. Willing, desire, immanently expresses the need for meaning. Even if sense as such is absent, it drives man's desire 
to transcend the horizon of ultimate reality - the immanence in which modern philosophy persisted. Desire points not to the way things are, but to the way they ought to be. This is what Řiha calls the principle of relevance. Meaning is "wanted"; one cannot live without it-even if one does not seem to find it.

This distinction between rational and volitional "seeking" is well captured by Czech theologian K. Skalický: "The search for meaning presupposes a way or style of thinking that differs (radically) from the search for cause or purpose" (Skalický 1990, p. 263). While reason seeks cause, the will seeks meaning. It is a very different search compared to ontology and metaphysics. It is, according to Říha, a straightforwardly "mystical" method. What does he mean by this word?

According to Říha, mysticism in principle is precisely such a "deeper" vision of reality in which we discover meaning. He likens it to the three stages of the discovery of meaning. First, man is accompanied by the loss of meaning, symbolising the shipwreck of classical, philosophical theories. It concerns both old ontological or theoretical explanations, but also one's own existential beliefs. Through this collision, man identifies himself not only as bodily and sensual, but above all as searching and dissatisfied. Through this crisis, he reveals deeper than his superficial foundation. Consequently, the stage of meaningemptying sets in, which consists of the recognition that even the things around us, by their very immanence, cannot explain and justify themselves-a position which, according to Ř́ha, can be all the more authentic and honest the more it is already personally conceived and at the same time stripped of the various illusions and convictions that were theoretical.

According to Říha, non-believers are very close to "meaning" in this "nihilistic" experience and tend to be very authentic in this search. They seek it precisely because they need it, thus sincerely expressing their needs. And they discover something that previously seemed irrelevant, irrational and foolish to them.

Such an awareness, such a discovery, is what Říha calls a "mystical" experience. Whenever in life a person experiences it as a "shipwreck" of his ideas-it always enables him to go deeper in his search. He can go deeper because the surface of things has disappointed him. He wants to go deeper because there is depth. The surface does not sufficiently explain the origin of things. The depth in his desire and search indicates something he knows differently. And so, man automatically inquires and searches for something deeper. And then he finds a new, intensified sense that leads him from the discovery of his own spirituality, his own wanting and meaning to the discovery of something Other that transcends ontological and metaphysical categories and realises a different will behind them.

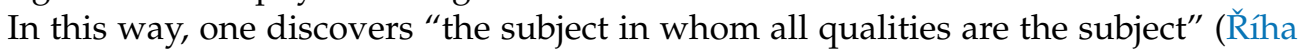
2004, p. 64). This Transcendence places before us a choice-optio (Blondel even calls it optio fundamentalis) - either to surrender ourselves to the One who transcends us and not be here for ourselves. It will change our life; we will lose control of ourselves. We will recede into the background as one who gives up the front rungs. But there is also a second option: to reject this Transcendence and focus exclusively on scientific knowledge and the objects of this world, to declare ourselves master of the whole world. The consequence of this, according to Říha, is the loss of that sense.

Říha speaks here of a twofold possibility: either to remain open, and as a consequence of this openness we will find and know new horizons of being (Řiha calls it "being in knowledge"). Or the possibility of remaining closed, the consequence of which is that one perceives everything around him to be "positive privation". This twofold alternative of basic choice is, according to Říha, asymmetrical: one cannot opt for both of them and remain in the right. If we answer the first way, we complete our action and confirm our presupposed ontological and ethical postulates. A negative answer-on the contraryimplies a renewed shipwreck of our cognitive and ontological principles, a groping and fragmentation. The difference between the two is that if in one's positive response one encounters "nothingness", it still means for him, at that moment, a rebirth to a new life (as an anticipation of a future death). But in the case of a negative answer, the question of meaning resonates very intensely in man, and he does not receive an answer to it. According 
to Řiha, our life does not begin with us-with our act, our effort and our decision. This mystical plane of our new life likewise begins with our choice, but it culminates in absolute passivity and absolute surrender.

Řiha interprets the experience of nothingness in the spirit of Nietzsche and Blondel as an "impulse" and "feature" of infinity, if we look at this nothingness for a long enough time (Welte 1994, p. 43; Rathouzská 2021, p. 88). Nothingness symbolises silence, which seems to be ambiguous in the highest degree. On one hand, to see and feel nothing, but on the other hand, something unconditioned can be seen in this experience. Thus, in experiencing nothingness, we may have the feeling and impression of something that reminds us very much of the unconditionality of religious experience. Nothingness is the source of a new and all the more intense religious experience in which, according to Řiha, we realise that our life does not begin with our effort and our decision, and we become increasingly aware of what we receive and how much we receive.

Pure devotion, surrender without a particular, concrete form of surrender, seems to be a transcendental assumption-as in the case of the question. One's decision always takes place at the interface of despair of the unknown and intuition of trust. At the edge of the known and the unknown. And the result of this step into the void is conversion, a fundamental choice (optio fundamentalis) because it cannot be grounded in purely rational motives. In this sense, such an act is mystical. It is mystical because it does not take the immanent into account, but what appears relevant-God (Říha 2007, pp. 7-8).

This goal is unattainable for us by way of reason. Intuition tells us of the possibility of God's existence. But the transcendental subject — as postulated by Rahner-brings us only to the content of our consciousness-not to Transcendence itself. As does the postulate of the will-in the case of such a transcendental object. Accessible to us, according to Ř́ha, is only that which is between the two extremes-entre deux as B. Pascal and M. Blondel. In such an ultimate goal, the light invisible to reason and the radiant darkness of nothingness unites. In this ideal, the subject-object paradigm to which ontological thought is bound is transcended (Říha 2012, p. 16; 2013).

For Řiha, the supernatural is-like Blondel's - absolutely unattainable on our part, though absolutely necessary. Therein lies the completion of our activity, the finding of our own identity and thus the consistency of our world. In it is the vinculum substantiale of the supreme activity of effort and the unconditional passivity of devotion, the unification

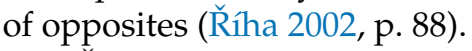

Ŕiha often referred to the term hymen in the work of Blondel who wrote: "The supernatural, then, is not God Himself; nor is it a created thing that would be attached and added to man: it is a sort of hymen between the soul and God. Consequently, we must not think of a simple accident, an arbitrary enhancement, a form extrinsic to man or a truth intrinsic to God: it is, in the consecrated phrase, an adoption, an assimilation, an incorporation, a consortium, a transformation that at once assures both union and distinction of the two incommensurables through the bond of charity. (...) For at issue is rather an incorporation of the divine life in man, and a presence in man of a supernaturalising action; at issue, moreover, is a cooperation wherein God and man each bring their contribution to a true symbiosis, which the sacred texts compare to a hymen. So that to refuse this union is to commit a sort of adultery. So true is this that the call to the supernatural is for man a fact at once imposed and consented to, which takes away any possibility of avoiding it reasonably. All of Christian morality and mysticism are conditioned thereby and are intelligible and viable only from this fully comprehensive standpoint" (Blondel 2021b, pp. 152, 201).

Devoutness to something that transcends us represents the highest act of the will and the renouncement of one's own will. It is the unity of activity and passivity. If this act does not finish in emptiness but meets other transcendental will which loves us, we find ourselves within the universal coherence with all that exists. This is where the true basis of metaphysics lies-in interpersonal relations. Through this we transcend (surpass) the classic requirements of metaphysics. Řiha asks if it still concerns metaphysics. Isn't it more likely an intellectual intuition united with unconditional devoutness? Isn't it 
a gift that surpasses natural abilities of the isolated subject? We can join Ǩíha and ask further questions: isn't this a mystical aspect of metaphysics? Or more precisely-is it the transcendence of metaphysics and the entrance into the territory of mysticism? Říha noted that Kant admitted the possibility of intellectual intuition. Kant affirmed that we do not have any experience related to this matter and in such a spiritual condition we would not think in accordance with categories of cogitation. The Czech philosopher agrees-discursive is surpassed just like the effort of the will that transforms into sheer devoutness. Perfect devoutness to another person is demonstrated by love. Morality is cancelled, obsolete, surpassed in the act of love. This transformation of morality cannot be substantiated according to the logic of identity, which is the logic of the consciousness. Actually, it is the entrance into unconsciousness. But the decision for devoutness represents

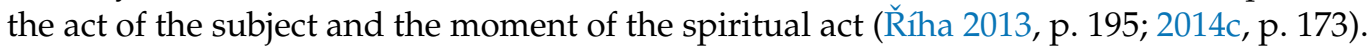

In the view of the Czech author, intellectualist systems of modern subjectivism and reflexive philosophies in general are wrecked on perception and understanding of meaning, which includes the relation between theoretical and practical reason. Thus, they deny legitimateness of other open questions, e. g. in what sense we can talk about existence of unconscious, creative powers of the spirit, unconscious decision making and unconscious religiosity. Ǩ́ha understood his attempt to find the resolution emerging from perception of metaphysics as universal mediation not as the final solution but as the entrance to mystery. It is true particularly regarding the question of the origin of conscience and its relation to creative powers of the spirit, art and love. This is the reason why interdisciplinary

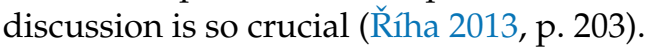

\section{Conclusions}

Contemporary Czech theologian Ctirad V. Pospísil assumes that the question of liaison (relationship) between metaphysics and ethics represents the analogy of the relationship between dogmatic theology and moral theology. Philosophical questions demonstrate surprising analogies with the relationship between both theological disciplines. He considers examination of their liaison to be important, referring also to thinking of Karel Říha. Pospísil assumes that for dogmatic theology it is important to perceive its interconnection with moral theology in the right way. To overlook moral theology, underestimate it or support its absorption would be incorrect, absurd and ultimately "suicidal" from dogmatic theology's point of view. Naturally, it is also true vice versa. If anyone attempted to give priority to dogmatic theology and from certain aspect also to mysticism, as we call it, he would risk slipping into "immorality" in spite of his knowledge. However, if anyone put morality above everything and neglected the grace of contemplation, he would be exposed to the threat of "godlessness" (Pospísil 2011, pp. 34-35).

Ǩíha was convinced that pure reflection separated from life cannot be seen as a method of theology. Life consists of expectation, anticipation of future associated with our return to the beginning. Particular disciplines can be limited to reflection, because their subject is represented only by a certain aspect of reality. However, theology as universal science dealing with living God, man, act of faith and the Church cannot remain limited to the level of pure reflection. Does it testify about unscientificity of theology? Or is theology some other, more universal human activity? Theological reflection is a creative comprehension of

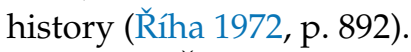

Karel Říha experienced something similar to Augustine. He wrote about his first experiences through which he started to understand a deeper meaning of creation. All of a sudden, everything was intimately familiar and close. However, the light of this experience faded and narrowed to occasional small fragments or glimpses. But since then, he has been able to embrace anxiety transforming in his arms into nothing (nothingness). He found out that anxiety has no body, it is baseless (Ǩíha 2010, p. 109). He realised that the truth is not under our influence, but we are chased by it. He unified with the Will about which we do not know where it might lead us and what it might ask from us. Nothing of his own 
remained within. We can say that metaphysics and mysticism are unified yet differentiated in his works.

Contemporary philosophy considers the central concept of mysticism to be the direct and intimate unity of the spirit with the fundamental principle of being (Waterlot 2013, p. 1363). In the first part of the thesis, we showed that Říha had undergone such an experience of unity. His interior was filled with compassion for all suffering and forgotten beings. He was reconciled to himself and to all creation. Reality became friendly to him, and he felt embraced and filled with it. He interpreted this experience as a work of "light power", a force that transcended the power of human motivations. Grace reached him and brought him above his ordinary, egocentric way of thinking. He ceased to be enclosed only in his own perspective and opened to friendship. A decision was born in him, "I will serve even if they don't understand me." Other experiences followed that confirmed that decision, a stepping out, a free act opens up a new experience with the world and oneself. Man wants to find his identity and his truth within himself, but, according to Říha, he will find it only when he detaches himself from the assumptions of his science, his leadership, and steps into the unknown. Then he is joined by the invisible Unknown who reveals the truth to him (Říha 2010, p. 102).

The mysticism of Karel Řiha transcends the traditional view of the relationship between mysticism and ethics. Firstly, it is based on moral conversion, i.e., the free decision to embark on the path of radical engagement. "We know that we have passed from death to life because we love the brethren. Whoever does not love remains in death" (1 Jn 3:14). The mystical experience of rebirth has the one who has taken the path of love for the brothers. One cannot be sure of this beforehand, but he will understand it after the act. The decision to serve causes a change within, a change of vision, but also a sense of oneness with others and with the deep, divine basis of reality. Secondly, conversion as a mystical turn is not something exceptional (Říha 2010, p. 101). On the contrary, according to Říha, everyone's life makes this experience possible and tends towards it. It is something intrinsic and familiar, though often repressed, neglected. The only obstacle is prejudice, the desire to control one's life, not to go into the unknown. We want to know what the step of surrender will bring us at first, and only then we might decide to take it. But in doing so, we make it impossible for the light power to give us a new perspective, a new experience, a new life.

That is why in his texts and speeches the Czech author also wrote and spoke about the natural certainty of simple people. These live without reflection in devotion to other people and in this devotion, they perceive the ineffable truth of life. How else could we explain the heartfelt concern for the good of others, the joy of selfless good deeds, hope in a hopeless situation, etc...? Based on these facts, it is clear that, without reflection, man somehow achieves a goal that philosophy considers unattainable, even internally contradictory: the unity of self-consciousness and devotion as two inseparable yet distinct moments of the same act (identity and relevance). It is a devotion in which the subject does not lose itself to itself (for itself); at the same time, it is a self-consciousness that is present to itself as real. These two moments, which are mutually conditioned and present in every human act, are to be explicated-explicitly realised and freely assumed-in conscious and responsible

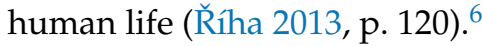

According to Říha, "our identity is possible only in unification with Christ. In Christ myself becomes truly mine through devoutness to someone else, which means liberating from the heaviest burden-one's own self" (Ǩíha 1998, p. 93). On one hand, identity represents something new, but on the other hand it remains authentic, yet completely transformed. In confrontation with other absolute You, given the relationship is unbalanced, there is no validity of classic categories where the person searches for meaning and finds it (Sinngebung and Sinnfindung) as his/her own "expectation", "need" to find self-confirmation. Absolute You brings out "fullness of unimaginable meaning" (Říha 1998, p. 206). Meaning is a substantiated consent which man does not give to himself. This is even more true in the case of absolute You, where the consent emerges from Him. In such a "mystical" encounter, the person is ripped out from "his/her own isolation of unredeemed 
self-love" (Ǩíha 1998, p. 121) with intensity that depends on His ability to transcend the category of human person. Hence, man is not left alone on his way toward meaning anymore. He becomes part of commūnio, which is the core of Christianity. Because "Christianity offers shared communion against shared isolation".

Author Contributions: All authors contributed equally to this paper. Conceptualization, M.V., A.B. and R.N.; methodology, M.V.; formal analysis, M.V.; investigation, M.V., A.B. and R.N.; resources, M.V.; writing—original draft preparation, M.V., A.B. and R.N.; writing-review and editing, M.V., A.B. and R.N., supervision, M.V., A.B. and R.N. All authors have read and agreed to the published version of the manuscript.

Funding: This article was funded by the Slovak Research and Development Agency under the contract No. APVV-17-0158 Perspectives religiosity development in Slovakia and by the Česká province Tovaryšství Ježišova under the grant number Z-21-104/0029-00 The Question of Ethics and Virtue Ethics in the Context of the Work of William Ockham.

Institutional Review Board Statement: Not applicable.

Informed Consent Statement: Not applicable.

Data Availability Statement: Not applicable.

Acknowledgments: We acknowledge the anonymous reviewers for their valuable and relevant comments and Daniel Goodall for final English editing.

Conflicts of Interest: The authors declare no conflict of interest.

\section{Notes}

$1 \quad$ Karel Říha was born on 11 May 1923 in Radkov na Morave. In 1943 he graduated and began to study theology in Brno and at the Lateran University in Rome. After a year, he joined the Society of Jesus and returned to Czechoslovakia, where he completed his novitiate. On the fateful night of "Action K" (elimination of monasteries on the night of 14-15 April 1950), he was transferred to a labour camp in Bohosudov and Osek, where he remained in forced labour for two years. After being released from the camp, he worked for many years as a worker in agriculture and construction. It was not until 1968 that he managed to emigrate to Innsbruck, where he finished his theological studies and obtained a doctorate in philosophy. In 1979 he left to work for the Czech editorial office of Vatican Radio and worked for the Nepomucenum College. From 1990 he taught at the Faculty of Theology in Olomouc. He died on 13 June 2016.

2 We refer in this context to an interesting dissertation "A Generative Truth: The Adaequatio Mentis et Vitae as Mystery of Fecundity in the Philosophy of Maurice Blondel". Its author remarks: "Action's fecundity is rooted analogically in the circumincessive communion that is divine, trinitarian acting. In its openness to Christian Revelation, Blondel's philosophy shows how truth as the union of intellect (intellectus) and its object (rei) is ultimately realised for man in the supernatural adequation of mind (mentis) and life (vitae) — that is, personal contemplation of divine life by participation in God's acting" (Caitlin 2021).

3 Oliva Blanchette notes: "Hence the question of something further and deeper than the phenomenon remains, along with the question of whether anything can resolve this problem of a gap still found in our voluntary action between our willed will and our willing will, the question that eventually leads to the question of God as active in our voluntary action, and the question of whether and how God can or wills to bridge this gap for the sake of bringing our action to a perfect coincidence of our willed will with our willing will" (Blanchette 2011, p. 148).

4 Radim Palouš (1924-2015) was a student of an important Czech phenomenologist Jan Patočka (1907-1977). He is considered the father of Czech philosophy of education and theology of education (Svobodová 2014, p. 208). His book Čas výchovy/Time of Education, the subject of which is conversion as the goal and problem of education, was first published in 1987.

5 Specifically, this means: I know the willing of Being. I will the knowing of Being. I am the knowing of willing. We still have to go through this cycle in the other direction too: I know the Being of willing. I will the Being of knowing. I am the willing of knowing. Of certainly, one could also speak of the so-called "mystique of the everydayness". It can also be expressed and characterised in these words: "Living faith means contemplating the Creator, contemplating others, contemplating oneself and the whole world. Contemplating the origin of my life, time and eternity—and immersing myself in the mystery of God's presence. To make of the encounter with God a mentality of the everydayness, from which I grasp impulses, inspirations and creativity, for the actions of the everyday moments of my being. With the Creator, to become co-creator of a good and beautiful world. (...) To empathise, co-create and co-make, equally with the dignitary and the homeless. To co-belong to the great whole of love, to fall down and get up - with our gaze fixed on eternity — this and many other ways of living the faith can be lived" (Pružinec 2021, p. 25). 


\section{References}

Blanchette, Oliva. 2011. Why we need Maurice Blondel. Communio: International Catholic Review 38: 138-67.

Blondel, Maurice. 1966. L'Itinéraire philosophique de Maurice Blondel. Propos Recueillis par Frédéric Lefèvre. Paris: Editions Montaigne.

Blondel, Maurice. 1935. L'Être et les êtres. Essai d'ontologie Concrète et Intégrale. Paris: F. Alcan.

Blondel, Maurice. 2021a. Action (1893). Notre Dame: University of Notre Dame Press.

Blondel, Maurice. 2021b. Philosophical Exigencies of Christian Religion. Notre Dame: University of Notre Dame Press.

Bocken, Inigo. 2020. God in Human Action. Mysticism, Philosophy and Theology in Maurice Blondel. Studies in Spirituality 30: 47-69. [CrossRef]

Caitlin, Jolly. 2021. A Generative Truth: The Adaequatio Mentis et Vitae as Mystery of Fecundity in the Philosophy of Maurice Blondel. Available online: https://www.johnpaulii.edu/images/content/Abstract_C_Jolly.pdf (accessed on 21 December 2021).

Ciraulo, M. Jonathan. 2021. Maurice Blondel and His Prodigal Children: Phenomenology, Charity, and Metaphysics. Theological Studies 82: 310-31. [CrossRef]

Conway, Michael A. 2018. Maurice Blondel and the Mystic Life. Ephemerides Theologicae Lovanienses 94: 661-92.

Kučerková, Magda. 2020. Interpretácia mystickej skúsenosti na pozadí fenomenológie Jeana-Luca Mariona. World Literature Studies 3: $16-28$.

Palouš, Radim. 1991. Čas Výchovy. Praha: Státní pedagogické nakladatelství.

Pospíšil, Ctirad V. 2011. Podněty k hlubšímu promýšlení poměru mezi dogmatickou a morální teologií. AUC Theologica 1: 7-35. [CrossRef]

Pružinec, Tomáš. 2021. Devät' dní s Pavlom Straussom alias deviatnik láskavého človeka. Od skalpela k filozofii, od filozofie k poézii, od poézie k mystike a od mystiky ku skalpelu. Gelnica: Vydavatel'stvo G-Ateliér.

Rathouzská, Lucie. 2021. Metafory světla a temnoty a smysl překonání imaginace v mystice Waltera Hiltona. In Studia Capuccinorum Boziniensia. Edited by Ladislav Tkáčik. Pezinok: Vydavatel'stvo Minor, Kapucíni na Slovensku, vol. 6, pp. 88-114.

Říha, Karel. 1972. Metafysika ducha, metafysika bytí a metoda teologie. Studie 15: 882-92.

Říha, Karel. 1987a. Zásady duchovního života. Studie 30: 101-36.

Říha, Karel. 1987b. K otázce založení ontologie subjektivity. Studie 30: 441-58.

Říha, Karel. 1990. Teorie konverze-Univerzální filosofická teorie? Studie 33: 327-39.

Říha, Karel. 1993. Filozofie Konání. K 100. Výročí Blondelovy "L'action". Olomouc: Matice cyrilometodějská.

Říha, Karel. 1996. Pravda a dialog. Teologické Texty 1: 8-12.

Říha, Karel. 1998. Zrození Ducha. Praha: Vyšehrad.

Říha, Karel. 2002. Identita a Relevance. Pokus o Vzájemné Uzásadnění Ontologie a Etiky. Svitavy: Trinitas.

Říha, Karel. 2004. Úděl člověka podle Maurice Blondela. Teologické Texty 2: 63-65.

Říha, Karel. 2005. Vzájemné uzásadnění ontologie a etiky. Studia Theologica 1: 30-40.

Říha, Karel. 2007. Transcendentální metoda. Studia Theologica 3: 1-8.

Říha, Karel. 2010. Hledání Středu. Svitavy: Trinitas/Řím: Křest’anská akademie.

Říha, Karel. 2012. Morální důkaz existence Boha podle Kanta. Studia Theologica 1: 1-29.

Říha, Karel. 2013. Nevědomý duch, jeho probuzení nebo nové zrození? Poznámky a otázky k logoterapii Viktora Emmanuela Frankla. Studia Theologica 1: 182-204. [CrossRef]

Říha, Karel. 2014a. Pojmy identita a relevance. In Dialektika mysli a činu. Filosof Karel Říha, SJ—Devadesát. Edited by Lucie Kolářová, Milan Nakonečný, Július Pavlečík, Karel Říha, Karel Skalický, František Štěch and Tomáš Veber. Svitavy: Pavel Sejkora-Trinitas, pp. 118-23.

Říha, Karel. 2014b. Nástin dějin problému existence Boha. In Dialektika mysli a činu. Filosof Karel Řîha, SJ-Devadesát. Edited by Lucie Kolářová, Milan Nakonečný, Július Pavlečík, Karel Ř́iha, Karel Skalický, František Štěch and Tomáš Veber. Svitavy: Pavel Sejkora-Trinitas, pp. 124-29.

Říha, Karel. 2014c. Doslov k vlastním příspěvkům. In Dialektika mysli a činu. Filosof Karel Řiha, SJ—Devadesát. Edited by Lucie Kolářová, Milan Nakonečný, Július Pavlečík, Karel Říha, Karel Skalický, František Štěch and Tomáš Veber. Svitavy: Pavel Sejkora-Trinitas, pp. 170-73.

Skalický, Karel. 1990. Požadavek smyslu a idea Boha ve světle fenomenologie náboženství. Studie 33: 242-70.

Skalický, Karel. 2014. Filosofie Karla Říhy a pokus o dialogické filosofování s ním. In Dialektika mysli a činu. Filosof Karel Říha, SJ—devadesát. Edited by Lucie Kolářová, Milan Nakonečný, Július Pavlečík, Karel Říha, Karel Skalický, František Štěch and Tomáš Veber. Svitavy: Pavel Sejkora-Trinitas, pp. 11-58.

Svobodová, Zuzana. 2014. Profesor Radim Palouš devadesátiletý. Teologické Texty 25: 208.

Štech, František. 2014a. Fundamental Theology, Dynamics of Christian Life and Identity. New Impulses for Fundamental Theology. ET-Studies 5: 77-95.

Štěch, František. 2014b. Integrální apologetika včera a dnes. In Dialektika mysli a činu. Filosof Karel Řîha, SJ—Devadesát. Edited by Lucie Kolářová, Milan Nakonečný, Július Pavlečík, Karel Říha, Karel Skalický, František Štěch and Tomáš Veber. Svitavy: Pavel Sejkora-Trinitas, pp. 59-76.

Waterlot, Ghislain. 2013. Mystique(s). In Dictionnaire Encyclopédique D'éthique Chrétienne. Edited by Laurent Lemoine, Éric Gaziaux and Denis Müller. Paris: Cerf, pp. 1363-371.

Welte, Bernhard. 1994. Světlo z Nicoty. O Možnosti Nové Náboženské Zkušenosti. Praha: Zvon. 